\title{
EXPANDING POLICE EDUCATORS' UNDERSTANDING OF TEACHING, ARE THEY AS LEARNER-CENTRED AS THEY THINK?
}

\author{
Brett Shipton \\ School of Policing Studies, \\ Charles Sturt University, AUSTRALIA \\ bshipton@csu.edu.au
}

\begin{abstract}
Police educators, that is, police and non-police teachers involved in recruit education and training, have traditionally suffered from a lack of organisational focus on developing their teaching and learning practices. The New South Wales (NSW) Police College, which is currently implementing Problem Based Learning $(P B L)$, has begun to take a more active role in developing staff to improve the uptake of learner-centred teaching approaches. Drawing on the current literature in relation to teaching approaches and conceptions, this paper outlines the findings from a survey of NSW Police College staff to determine their dominant teaching approach prior to extensive staff development that commenced in 2010. The paper highlights contradictions in the survey findings, with responses to closed questions indicating a majority favouring learner-centred approaches, while responses to open-ended questions suggest staff tend to be more teacher-centred. Discussion of these results highlights several possible reasons for this contradiction and suggests that further development of staff teaching conceptions is required to encourage reflective practice and the use of learner-centred approaches crucial to the facilitation of PBL. This discussion provides a basis for suggestions in relation to the design of staff development programs for police educators based on variation learning theory.
\end{abstract}

Keywords

Police education, teacher development, variation learning theory

\section{Background}

\section{Variations in teaching approaches and their impact on student learning}

There has been a body of research developing since the early 1990's examining the conceptions university academics hold in relation to their teaching role. Prior to this, research and staff development activities in relation to academics' teaching roles focused on specific teaching strategies and methods rather than the underlying conceptions teachers hold about their teaching practice (Trigwell \& Prosser, 1996). Kember (1997), in a review of key studies in this area, highlighted the need to understand and recognise teaching conceptions in order to improve staff teaching approaches and therefore enhance the quality of student learning. The importance of understanding teaching conceptions can be seen in the impact they have on teaching practice and the flow through effects on student learning (Kember, 2009). 
Research in this area has identified two broad categories of teaching approaches that Kember (1997) characterised as teacher-centred/content-oriented and student-centred/learning oriented. These will simply be referred to in this paper as 'teacher-centred' and 'learner-centred' respectively. A teacher-centred approach places the teacher at the centre of the learning environment, transmitting information in the form of isolated facts and skills to students, who assume a relatively passive role that is dependent upon the teacher's actions and knowledge. This is in contrast to a learner-centred approach, which assumes a significant focus upon student learning needs, the development of conceptual understandings via active learning and an assumption that students tend to be more proactive and self-directed in their learning approaches (Åkerlind, 2007; Conti, 1989; Kember, 1997; Ramsden, 1992; Trigwell, Prosser \& Waterhouse, 1999). Åkerlind in her summary of previous studies highlighted two key differences or aspects of variation in relation to these approaches to teaching that include:

- A variation in focus from transmission of information to students to the development of conceptual understanding in students; and

- An associated variation in focus from the teacher and their teaching strategies to the students and their learning and development (2007, p. 22; emphasis in original).

Within the studies in this area, there has been a general consensus that conceptions ranging towards a more learner-centred practice, with their emphasis upon conceptual understanding and student learning, represent a more sophisticated and effective model of teaching (Åkerlind, 2007; Kember, 1997).

Recognising the importance of learner-centred teaching in promoting more desirable learning outcomes can be traced back to the research on student learning approaches, beginning with a key study in Sweden by Marton and Saljo (1976), where their examination of students reading a text highlighted two broad approaches to learning. They noted one group of students memorising a list of disjointed facts from the text in anticipation of being asked to recall these details. This was described as a 'surface' approach to learning. The second group of students did more to interpret the underlying meaning of the text in order to explain what the author was trying to say. This was described as a ‘deep' approach to learning. A range of further studies, including those of Biggs (1978) and Entwistle and Ramsden (1983), continued to demonstrate differences in surface and deeper approaches to learning. Importantly, further studies, including those by Trigwell, Prosser and Waterhouse have also "consistently shown that deeper approaches to learning are related to higher quality learning outcomes” (pp. 57-58). Correspondingly, Biggs (1999) suggests surface learning provides inadequately low levels of cognition, which yield only fragmented information without conveying appropriate levels of meaning. He contrasts this with deeper learning to achieve quality learning outcomes, where students undertake activities that result in higher levels of cognition by explaining, applying and theorising knowledge in a way that allows a more effective transfer of learning to real world practice.

In a study linking the teaching and learning conceptions of teachers, Trigwell and Prosser (1996) reported that teachers with a more sophisticated learner-centred conception viewed learning as conceptual change, with those having a teacher-centred approach viewing learning as the transmission of information. A further study by Trigwell, Prosser and Waterhouse (1999) suggested teachers using a teacher-centred approach were more likely to encourage surface learning approaches in their students. There was also a converse, but slightly weaker, relationship indicating teachers who adopted a learner-centred approach encouraged deeper learning approaches in their students. Studies by Kember and Gow (1994) reported similar findings, with a knowledge transmission orientation (teacher-centred) causing less desirable learning and a learning facilitation orientation (learner-centred) encouraging more meaningful learning. Importantly, these studies highlighted the need for staff development activities to encourage the adoption of learner-centred teaching approaches in order to improve the student experience and the quality of their learning outcomes (Kember \& Gow, 1994; Trigwell \& Prosser, 1996). The survey discussed in this paper indicates some of the areas that should be considered when designing these activities. 


\section{Developing staff to encourage learner-centred teaching}

Importantly, however, it should also be highlighted that developing teachers' conceptions is not necessarily a simple switch from teacher-centred to learner-centred thinking. Whilst highlighting these two broad orientations, Kember's review indicated that a range of previous studies of this topic suggested there were a number of stages differentiating teachers' conceptions along a teacher-centred to learner-centred continuum (see Figure 1). Kember (1997) suggests that the lower level of this model highlights a number of transitional stages teachers progress through to more advanced understandings of teaching practice. The model indicates that transitions within the broader domains, for example from Imparting Information to Transmitting Structured Knowledge are relatively easy; however, moving from the Teacher-centred to Student-centred domain is a more difficult and complex conceptual shift (Kember, 1997).

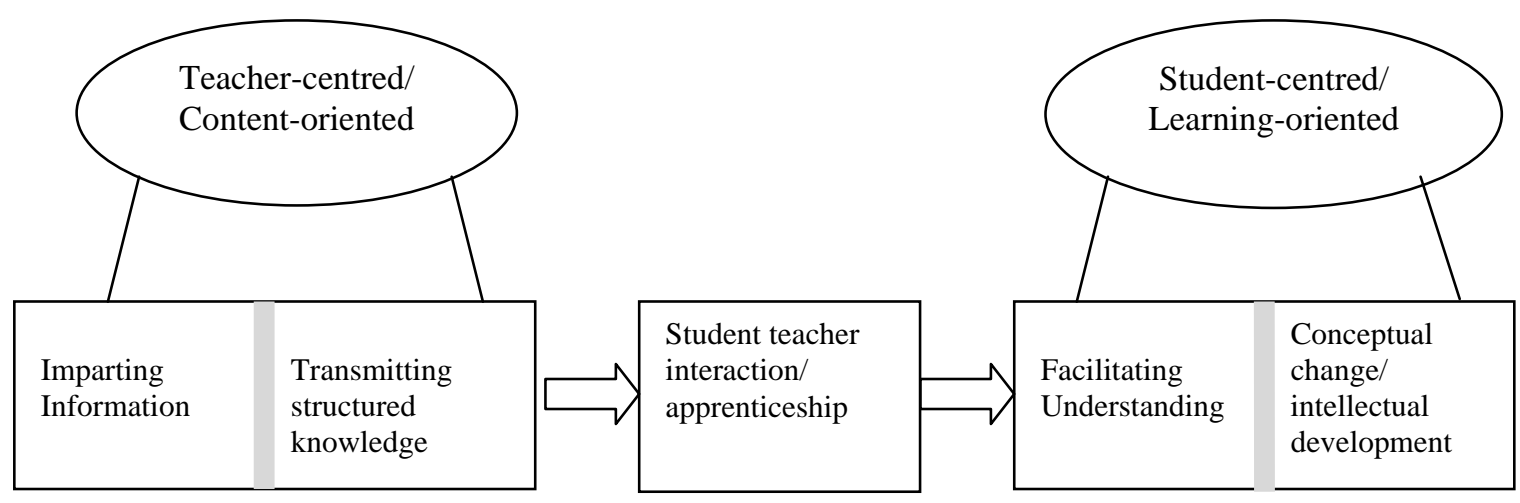

Figure 1. Stages of teacher conceptions of learning (adapted from Kember, 1997, p. 264)

This model has been refined over the past decade, with further studies questioning the existence of the middle or transitional stage, preferring to consider all conceptions as either teacher-centred or learner-centred (Kember \& Kwan, 2000; Samuelowicz \& Bain, 2001). Samuelowicz and Bain (2001) in particular, identified six separate orientations, with three under the heading of teachercentred and another three under learner-centred. However, what remains is the need for staff development activities that promote changes in teaching conceptions or beliefs in order to assist teachers in transitioning through these stages from teacher-centred to more learner-centred approaches (Kember \& Kwan, 2000).

A range of studies in the area of teaching conceptions and approaches have used phenomenographic research, some examples being Martin and Ramsden (1992), Prosser and Trigwell (1999), Åkerlind (2003) and McKenzie (2003). There are some key ontological differences between phenomenography and more cognitive perspectives used by authors such as Samuelowicz and Bain (2001) and Kember (1997), with these latter taking a different perspective on conceptual development. From a cognitive perspective, development is seen as conceptual change, which implies teacher-centred and learner-centred conceptions are independent of each other along a continuum of development (Åkerlind, 2008). When viewing this development within Figure 1 above, a person is seen as replacing one system of belief (teacher-centred 
conception) with another (learner-centred). This contrasts with a phenomenographic perspective, where conceptions are seen as related within a hierarchy of inclusiveness, implying development towards a more learner-centred understanding resulting in conceptual expansion (Åkerlind, 2008, emphasis in the original).

An example of a phenomenographic research approach demonstrating expansion within a hierarchy of inclusiveness can be seen in a study by Åkerlind (2007) to establish ways university practitioners approached their growth and development as teachers. Five qualitatively different approaches emerged to include:

- Category 1: Building up a better knowledge of one's content area, in order to become more familiar with what to teach;

- Category 2: Building up practical experience as a teacher, in order to become more familiar with how to teach;

- Category 3: Building up a repertoire of teaching strategies, in order to become more skilful as a teacher;

- Category 4: Finding out which teaching strategies do and don't work for the teacher, in order to become more effective as a teacher;

- Category 5: Continually increasing one's understanding of what works and doesn't work for students, in order to become more effective in facilitating student learning (p. 27; emphasis in original).

This framework represents the increasing awareness of variation from initial teacher-centred approaches (becoming more familiar with subject content), to more complex and sophisticated learner-centred views of teaching (becoming more effective in facilitating student learning). This phenomenographic framework recognises that each category builds upon and subsumes the understanding and skills within earlier categories, as teachers gradually becoming more aware of the wider variations in their practices (Åkerlind, 2007; Trigwell \& Prosser, 1996). For example, in the initial development stage, Åkerlind (2007) suggests the main focus for a teacher is to build up their level of content expertise, with limited thought for more experience or skill development in teaching methods. However, if a teacher moves beyond this initial stage to recognise the need to further develop their skills and understanding of teaching, there will still be a need for that teacher to refine their content knowledge; it now just becomes one of a number of priorities to improve teaching practice rather than the sole focus. Again, it should be noted that each of these stages represents qualitative differences in a teacher's understanding of teaching rather than a quantitative increase in knowledge of teaching. Also on this view, less sophisticated understandings should not be regarded as wrong, rather as incomplete (Åkerlind, 2008).

Despite the differences in the assumptions of cognitive and phenomenographic perspectives, findings from both perspectives suggest teachers transition through a number of qualitatively more sophisticated stages in order to develop towards learner-centred conceptions of teaching. Crucially, this development of more sophisticated teaching conceptions is necessary in order to change the way teachers approach their teaching, as they are unlikely to utilise approaches that extend beyond the sophistication of their conceptions (Trigwell \& Prosser, 1996). Therefore, encouraging learner-centred approaches requires the broadening and developing of underlying conceptions of what teaching and learning means (Irby, 1996; Kember \& Gow, 1994). This approach requires a move away from traditional staff development approaches that simply highlight various teaching strategies and step by step guides to their use, to more sophisticated approaches that challenge current understandings and help participants become more aware of wider variations in teaching and learning (Åkerlind 2007; McKenzie, 1999; Trigwell \& Prosser, 1996). Whilst these findings provide significant insight into the direction for staff development programs, changing teacher conceptions remains a challenging task (Dahlgren, Castensson \& Dahlgren, 1998; Trigwell \& Prosser 1996). 


\section{Signs of change in police education}

Training and education programs for police recruits have begun to evolve in recent decades due to the increasing expectations placed upon police organisations to provide competent and ethical policing commensurate with community expectations. To design better learning programs, police educators have been compelled to look beyond more traditional and teacher-centred training methods to consider the more innovative and learner-centred teaching approaches being adopted by the broader adult education sector. The need for change has been driven by criticism that police recruit programs rely upon teacher-centred strategies and a narrow focus on skills training that have failed to promote the effective transfer of learning to the workplace and the problemsolving skills required in operational policing roles (Birzer, 2003; Bloss, 2004; Bradford \& Pynes, 1999; Chappell, 2005; McCoy, 2006).

One of the notable innovations within police education around the world, in particular in North America and Australia, has been the use of problem-based learning (PBL). PBL is a learnercentred teaching method that empowers learners to research their subject area and apply knowledge and skills to solve relevant ill-structured problems (Savery, 2006). Critical to this method is the teaching approach of the tutor, who facilitates the learning of small groups of students by guiding or scaffolding their thinking processes to promote deeper learning approaches or high level cognitive engagement, where students construct meaning and develop functional knowledge (Biggs, 1999). Research on PBL over recent decades indicates no clear advantage over traditional teaching methods in terms of memorising information. However it has been established that PBL can: be more nurturing and enjoyable (Albanese \& Mitchell, 1992), help students retain knowledge for longer periods and apply it to similar problems in the future (Norman \& Schmidt, 1992), help students exhibit better problem solving abilities (Savery 2006), and be more effective in the development of skills (Dochy, Segers, Van den Bossche and Gijbels, 2003).

However, despite the perceived benefits of PBL, its implementation into any education institution is not without a range of challenges, including the development of staff to design and facilitate the new curriculum. Irby (1996), in a review of PBL staff development programs, suggested faculty staff are initially sceptical of PBL because it confronts their deep beliefs about knowledge and teaching, thus it presents a dual challenge of transforming beliefs about teaching and learning whilst also providing specific facilitation skills. This challenge of changing teaching approaches in North American police education contexts has been highlighted by Berg (1990) and Marion (1998) who suggested police officers teaching in police academy settings are not adequately prepared for their teaching role. More specifically, research by McCoy (2006) and Werth (2009) suggests police educators are predominantly teacher-centred in their approach. McCoy (2006) also suggests that a lack of effective teacher training for police educators has limited the use of teaching strategies that can promote deeper learning. The research by Werth (2009) is also interesting in his comparison of two US police academies, one using PBL and the other not. He found that police educators in both institutions held predominantly teacher-centred beliefs, despite one of them having gone through a PBL implementation process.

The NSW Police Force has spent the past two decades integrating its recruit training into the higher education sector via a partnership with Charles Sturt University and has more recently commenced the implementation of PBL into the Associate Degree in Policing Practice (ADPP). Whilst a number of short Introduction to $P B L$ workshops were conducted internally for staff at the NSW Police College in late 2009, the more significant facilitator development workshops began in January 2010, with intensive five day workshops for staff being conducted by two consultants who had developed a version of PBL suited to police education - what they termed 'Police PBL' (Cleveland \& Saville, 2007). Their approach utilises the methods of authentic PBL (Barrows \& Wee Keng Neo, 2007) but also integrates the concepts of Emotional Intelligence (EI), based on the research of Daniel Goleman (1995), and Multiple Intelligences (MI), developed by Howard Gardner (2004). Their program also includes reflective journals, assessment rubrics and Bloom's Taxonomy to promote deeper learning experiences. Both the workshops and the ongoing certification and mentoring program within the NSW Police College are intended to encourage 
staff to challenge their underlying conceptions about teaching and develop their practice to incorporate more learner-centred approaches. Whilst the course designers did not base their course specifically upon the theories described by Trigwell and Prosser (1996) and Kember (1997), the goal to challenge conceptions and encourage change towards more learner-centred teaching has the same aim of changing conceptions of teaching.

\section{Methods}

The purpose of the survey discussed in this paper was to capture some understanding of teaching approaches and conceptions of staff prior to the intensive stage of the staff development program in early 2010. The guiding questions of the study reported in this paper were:

1. What is the dominant teaching approach of staff on the ADPP?

2. Is there a need for further development of staff teaching conceptions to fulfil the requirements of PBL?

Survey Monkey ${ }^{\circledR}$ was utilised to construct the questions in the current survey and disseminate them via work emails to approximately 70 police and University staff in teaching roles on the ADPP at the NSW Police College. Over a four week period in late 2009, there were 27 voluntary and anonymous responses to the survey received. The study was conducted with the approval of the School of Policing Studies Human Research Ethics Committee.

The survey comprised both closed and open-ended questions. There were nine closed questions asking participants to choose between yes or no responses, with three of these providing an opportunity for an 'other' option and narrative comments. Three open-ended questions allowed for narrative responses in relation to participants' teaching and their development in this role. A final open-ended question elicited general responses from participants in relation to the foreshadowed implementation of PBL and its impact on their subject delivery. The four openended questions were:

1. What do you think are some of the key attributes of a good teacher on the ADPP?

2. What are your greatest strengths as a teacher? In relation to this and the next question, it might be useful to consider student and peer feedback you have received.

3. What areas of your teaching could you improve upon?

4. In relation to the proposed changes to PBL in the ADPP, what concerns do you have in relation to the delivery of your subject?

These four questions were designed to elicit generalised approaches and conceptions of teaching, rather than focusing participants' attention on specific strategies highlighted in the remaining survey questions. The narrative data from the first three questions were analysed within the framework of qualitatively different approaches to growing and developing as a university teacher established by Åkerlind (2007). This framework was chosen because each additional stage represents an expanding level of understanding of the teaching role, providing a gauge for current approaches and conceptions, and potential for further development. It is anticipated that using other frameworks describing teaching approaches and conceptions, such as Trigwell and Prosser (1996) and Kember (1997), would have yielded similar findings due to the general similarities in the findings of various studies in this field (Åkerlind, 2007; Kember, 1997). However, the framework used in this study was chosen to highlight possible stages of development relating to staff at the time of the survey. For the purpose of this paper, there is no clear distinction made between approaches and conceptions, with the framework only being used as a general guide to categorising the participants' descriptions. It should be noted this is not a phenomenographic study.

The narrative responses were analysed in an iterative manner through repeated reading to identify similarities and differences with the definitions and examples described by Åkerlind (2007). The 
fourth open-ended question seeks to link participants' understanding of their teaching role to the PBL implementation and highlight issues or concerns that will impact their teaching. Key themes were noted in this question using a theoretical thematic analysis approach, which requires a more detailed analysis of data relating to the research questions (Braun \& Clarke, 2006). These themes were then synthesised with the results from the other questions in the final discussion.

\section{Findings}

The responses to open-ended questions in the survey mostly consisted of several lines, with some responses comprising several short paragraphs. When interpreting Questions 1 to 3, it was important to consider the hierarchical nature and inclusiveness of the five qualitatively different approaches to teaching described by Åkerlind (2007). For example, a respondent describing their teaching as becoming more effective in facilitating learning (equivalent to Category 5), may also highlight attributes described in any of the lower categories. From the perspective of a hierarchical structure, this is not viewed as inconsistent, but instead reflects a more sophisticated view of teaching that uses a wider range of approaches to facilitate effective learning (Åkerlind, 2007; Trigwell \& Prosser, 1996).

The results outlined in Table 1 (below) indicate a preference for Category 1 in responses to Question 1, with a focus upon the teacher building their content knowledge to become more familiar with what to teach. This approach reflects the teacher-centred strategies described above with the focus being upon subject content and its transmission (McKenzie, 1999). Comments within this category focused upon teachers' experience in, and knowledge of, policing. Some examples were "Sound knowledge of subject matter" (T25) and "Credibility derived from previous operational experience” (T17). In addition to highlighting better content knowledge, teachers in this category may also highlight enthusiasm, approachability and the ability to generate student interest (§̊kerlind, 2007). An example of this was "Patience, energy and a willingness to make a difference ...” (T2).

There were no responses matching Category 2, which highlights the importance of building up experience as a teacher to become more familiar with how to teach. There were several mentions of the need for experience; however, these related to the experience of being a police officer or teaching in related subject areas, so they remained in Category 1.

Descriptions of Category 3, reflecting the need to become more skilful as a teacher, matched $38.4 \%$ of respondents. Examples included “... applying teaching/delivery strategies to assist student learning” (T8) and “... able to identify different learning styles and cater for these in the program. Good knowledge of adult learning principles ...” (T14).

There were no findings matching Category 4, finding out teaching strategies that do or do not work to become more effective as a teacher, however, two respondents were matched to Category 5, becoming more effective in facilitating student learning. These two categories are similar but Category 5 emphasises the importance of improved student learning as an indicator of effectiveness, rather than simply becoming more satisfied and comfortable with teaching. Only two respondents $(7.7 \%)$ were placed in this category. One of these respondents, in addition to highlighting "knowledge of the subject area ...”, also indicated the need for “... constant assessment of students to be aware of whether learning is taking place” and also "... constantly facilitating and debriefing to draw the learning out of the lesson in a student centred way not a teacher didactic way” (T22). 
Table 1: Question 1 - Distribution of responses by category

\begin{tabular}{|c|c|c|}
\hline No match & 1 & $3.9 \%$ \\
\hline Category 1 & 13 & $50 \%$ \\
\hline Category 2 & 0 & $0 \%$ \\
\hline Category 3 & 10 & $38.4 \%$ \\
\hline Category 4 & 0 & $0 \%$ \\
\hline Category 5 & 2 & $7.7 \%$ \\
\hline & $\mathrm{n}=26$ & $100 \%$ \\
\hline
\end{tabular}

The responses to Question 2 in Table 2 (below) were similar to those in Question 1. Of the 27 responses, 55.6\% limited their descriptions to teacher-content focused strengths in Category 1. Examples within this category included "I have a broad policing background behind me and attempt to use this to convey learning points ..." (T2) and "Thorough knowledge of subject matter and ability to relay same to students ...” (T10).

As with Question 1 there were no responses matching Category 2, whilst responses to Category 3 provided a similar quantum to Question 1 at $37 \%$. Whilst most responses lacked significant detail, descriptions offering at least some indication of having or accumulating a variety of teaching skills or reference to specific teaching strategies, were placed in this category. Examples included "I am aware of a wide range of teaching strategies and I try to meet a range of teaching styles" (T1) and "Ability to explain concepts to students in many different ways so all students can understand and apply the content” (T7).

Again Category 4 was not represented in these responses, whilst Category 5 only had one response, highlighting "Considering and catering to the needs of students. Using experiential learning ..." and "Debriefing and facilitation skills" (T22).

Table 2 - Question 2 - Distribution of responses by category

\begin{tabular}{|c|c|c|}
\hline No match & 1 & $3.7 \%$ \\
\hline Category 1 & 15 & $55.6 \%$ \\
\hline Category 2 & 0 & $0 \%$ \\
\hline Category 3 & 10 & $37 \%$ \\
\hline Category 4 & 0 & $0 \%$ \\
\hline Category 5 & 1 & $3.7 \%$ \\
\hline & $\mathrm{n}=27$ & $100 \%$ \\
\hline
\end{tabular}

Responses to Question 3 provided a more even response across the categories described by Åkerlind (2007). Table 3 (below) indicates the distribution of responses into the relevant categories. It should be noted that $14.8 \%$ of responses did not provide a sufficient description to be placed into any of the categories. 
Descriptions matching Category 1, emphasising the importance of building a better knowledge of policing, were seen in $18.5 \%$ of respondents' comments. Typical examples of comments in this category included "Knowledge on the subject” (T4) and “Subject development” (T11).

Category 2, highlighting more practical experience in teaching to become more familiar with how to teach, was also matched to $18.5 \%$ of responses. Examples of comments in this category included "Need more face to face teaching" (T9) and "My diction and timing, as I have a tendency to race through material at times when teaching face to face” (T24).

Category 3 attracted the highest number of responses for this question with $37 \%$ of respondents giving descriptions that matched this approach. Responses in this category included: "How to facilitate groups more effectively" (T1), "Exposure to new and different teaching styles will inform and improve my teaching" (T3) and "varied delivery methods" (T18). Whilst some comments highlighted the need to learn about facilitation, these were not placed in categories 4 or 5 because they did not describe the need for discovery and reflective practice (Category 4 ) or the need to focus on student learning outcomes as an indicator of effective teaching (Category 5).

Categories 4 and 5 only attracted descriptions from one respondent each. The respondent to Category 4 highlighted their ability to “... utilize student feedback” (T26) to assist in finding out what does and does not work in their teaching approach. The respondent matched to Category 5 highlighted the importance of "Assessment of both myself and students which would include professional reflection" and also emphasised "the constant need to improve, debriefing and facilitation” (T22).

\section{Table 3 - Question 3 - Distribution of responses by category}

\begin{tabular}{|c|c|c|}
\hline No match & 5 & $18.5 \%$ \\
\hline Category 1 & 5 & $18.5 \%$ \\
\hline Category 2 & 5 & $18.5 \%$ \\
\hline Category 3 & 10 & $37 \%$ \\
\hline Category 4 & 1 & $3.7 \%$ \\
\hline Category 5 & 1 & $3.7 \%$ \\
\hline & $\mathrm{n}=27$ & $100 \%$ \\
\hline
\end{tabular}

Question 4, the final open-ended question, asked what concerns staff had in relation to the delivery of their subject and the PBL implementation. This question provided a range of responses that were grouped into three key themes. The first theme centred on concerns staff had with the delivery of their subject content. Key comments included: "Time will be taken away from my subject and I will not be able to cover all of my objectives" (T1), "time to cover as much material" (T2), "Teachers not having enough knowledge across the subjects to be effective” (T5), "May interfere with core subject teaching” (T15) and "That my subject area is not lost ...” (T22).

The second theme from Question 4 centred on concerns in relation to teaching and learning. Key comments in relation to this theme were: "Quality learning will result but will we have sufficient quantity?” (T2), “Teachers ... will revert to group discussions to save face and therefore fail in their duty to teach students what they need to know." (T5), "Concerns re unqualified staff teaching our subject” (T9), "Lack of instruction for facilitators; inconsistency of delivery ...” (T10) and “Concerned with future 'PBL lecturers' not relating/understanding PBL practice” (T21). Whilst each of these comments highlighted teaching practice, it is also interesting to note the first three linked teaching back to concerns with subject content not being covered. 
A third theme centred on the belief the NSW Police College is already using PBL practices. Some comments that reflect this thought included: "I think it is already taught in ways that reflect some PBL principles” (T13), “Currently (subject named) is basically PBL” (T17) and "I believe we are very close to PBL now” (T25).

Question 5, the first closed question, asked participants to choose between a teacher-centred perspective, describing their role as a 'subject matter expert', who should 'explain concepts to students in a structured way' or a more learner-centred perspective describing 'a facilitator, providing students with learning opportunities to construct and understand concepts for themselves'. A clear majority of staff, $66.7 \%$ agreed with the learner-centred response, with 29.2\% choosing the teacher-centred description thus agreeing that they were more of a 'subject matter expert' than a 'facilitator' (Table 4 below). However, $16.7 \%$ or seven of the total respondents also added a brief narrative comment. Five of these comments indicated that both approaches were relevant to their practice. One in particular indicated "Both A \& B - due to volume of subject matter students are required to know in short period of time I believe the ADPP requires both” (T10).

Table 4: Distribution of responses to Question 5

\begin{tabular}{|c|c|c|c|}
\hline $\begin{array}{l}\text { Question 5: } \\
\text { Which statement } \\
\text { most closely } \\
\text { describes your } \\
\text { understanding of } \\
\text { your current } \\
\text { teaching role? }\end{array}$ & $\begin{array}{l}\text { A: My job as the } \\
\text { subject matter expert } \\
\text { is to clearly explain } \\
\text { concepts to students } \\
\text { in a structured way. } \\
29.2 \% \text { agree }\end{array}$ & $\begin{array}{l}\text { B: see myself as a } \\
\text { facilitator, providing } \\
\text { students with learning } \\
\text { opportunities to construct } \\
\text { and understand concepts } \\
\text { for themselves. } \\
\mathbf{6 6 . 7 \%} \text { agree }\end{array}$ & $\begin{array}{l}\text { C: Briefly write your } \\
\text { own statement below } \\
\text { if you do not agree } \\
\text { with any of the } \\
\text { above. } \\
\text { 16.7\% indicated both } \\
\text { statements were true }\end{array}$ \\
\hline
\end{tabular}

Question 6 again asked for a choice between teacher and learner-centred perspectives, with 21.7\% indicating subject content was more important than particular teaching strategies, whilst the majority, 69.6\%, indicated a more learner-centred response of encouraging students to think about and make sense of subject content (Table 5 below). Given the opportunity to make further comment if they did not agree fully with the statements, $17.4 \%$, or eight respondents, made additional replies. Four of these responses highlighted that both statements can be relevant to their role. One respondent in particular suggested that, "Subject content is only valuable if students move beyond knowing it and are able to apply it in real policing situations” (T26).

\section{Table 5: Distribution of responses to Question 6}

\section{Question 6:}

In relation to the subject content you teach, which statement do you most agree with?
A: Subject content (what we teach) is a more important consideration in the classroom than the particular teaching strategy we use.
21.7\% agree

C: Briefly write your own statement below if you do not agree with any of the above.

$17.4 \%$ indicated both statements were true

Question 7 asked respondents to choose between three statements in relation to teaching goals, two more teacher-centred and one more obviously learner-centred. The first statement, highlighting the need for students to remember information, was chosen by 15.4\% (Table 6 below). The 
second statement, suggesting the study of scenarios to identify procedures, whilst not as obviously teacher-centred as the first statement, still emphasised knowledge of procedures rather than the more critical thinking response highlighted in the third statement. Only $11.5 \%$ agreed with the second statement. The third statement, highlighting the importance of self-directed learning and problem solving was chosen by $69.2 \%$ of respondents. Again, taking up the option of describing their own goal if they did not agree with any one statement, $11.5 \%$ or seven of respondents made additional comment. Two of these emphasised the importance of combining aspects of statements A and C, however, five respondents indicated various concerns about students' not acquiring content knowledge at the expense of self-directed learning and problem solving skills. Some of the comments in this category include:

You cannot get away from making sure students know key information ... You cannot put the cart before the horse, students need to know what is what and then identify such in scenario based problems (T5).

... both A and B unless more time can be allocated to each subject. There is generally too much information to be delivered in too short a time (T8).

and

... without adequate content knowledge, I don't think self-directed learning or problemsolving can effectively take place (T13).

Table 6: Distribution of responses to Question

\begin{tabular}{|l|l|l|l|}
\hline $\begin{array}{l}\text { Question 7: } \\
\begin{array}{l}\text { Which statement } \\
\text { most closely } \\
\text { describes your } \\
\text { preferred teaching } \\
\text { goal? }\end{array}\end{array}$ & $\begin{array}{l}\text { A: The most } \\
\text { important task for } \\
\text { students is to } \\
\text { remember key } \\
\text { information from the } \\
\text { subject content. }\end{array}$ & $\begin{array}{l}\text { B: Students should study } \\
\text { set policing scenarios so } \\
\text { they can identify the } \\
\text { correct procedure to use } \\
\text { for a given situation. }\end{array}$ & $\begin{array}{l}\text { C: Whilst content is } \\
\text { important, students } \\
\text { need to develop 'self- } \\
\text { directed learning' and } \\
\text { 'problem-solving } \\
\text { skills' they require to } \\
\text { continue learning. }\end{array}$ \\
$15.4 \%$ agree & \begin{tabular}{l} 
69.2\% agree \\
\hline
\end{tabular}
\end{tabular}

7

The remaining six questions in Table 7 (below) required yes or no answers to statements that tended to indicate teacher or learner-centred approaches. In Question 8, 44.4\% of respondents indicated they needed to make curriculum choices for their students because they (the students) could not be trusted, whilst the remaining $55.6 \%$ seemed to have some trust in the ability of their students to determine what they should or should not learn. A key limitation on this question, however, is the interpretation of the term 'curriculum'. The original intention of the question was to focus upon learning activities where students have the ability to determine their leaning needs, rather than questioning the broader learning outcomes of the program, perhaps accounting for a higher 'yes' response.

Question 9 had most respondents, 66.7\%, not intervening immediately to prevent confusion amongst their students, preferring instead to provide an opportunity for students to discuss and clarify their own understanding. The remaining third of respondents preferred a higher degree of control in this situation. An overwhelming majority of respondents, 88.9\%, in Question 10, preferred the use of open-questions and encouraging questions amongst their students. However, there was an almost even response, $44.4 \%$ yes and 55.6\% no, to Question 11, suggesting that respondents believe student learning decreases when the teacher is not directing activities in the classroom. Admittedly, this question may be limited by the interpretation given to directive 
activities. Even within a PBL classroom, there is a requirement for some degree of direction, however, with the proper development of self-directed and problem solving skills, the need for this direction should decrease.

The theme of control in the classroom continues with Question 12, which asks if respondents adhere to a consistent format and actions in each lesson. A clear majority of $70.4 \%$ indicate they do adhere to a format, suggesting less scope for students to control the direction of their learning. Finally, Question 13 provided a clear majority, 81.5\%, of respondents indicating the need to guide students' thinking towards an answer, rather than simply providing information.

\section{Table 7}

\begin{tabular}{|c|c|c|}
\hline $\begin{array}{l}\text { Question 8: } \\
\text { I like to make curriculum choices for students because I } \\
\text { can't trust them to know what they need to learn. }\end{array}$ & $44.4 \%$ yes & $55.6 \%$ no \\
\hline $\begin{array}{l}\text { Question 9: } \\
\text { When there is confusion between students in the } \\
\text { classroom, I immediately intervene to provide the correct } \\
\text { answer. }\end{array}$ & $33.3 \%$ yes & $66.7 \%$ no \\
\hline $\begin{array}{l}\text { Question 10: } \\
\text { During discussion, I ask many open-ended questions and } \\
\text { encourage students to ask questions of each other. }\end{array}$ & $88.9 \%$ yes & $11.1 \%$ no \\
\hline $\begin{array}{l}\text { Question 11: } \\
\text { If I am not directing activities in the classroom, the most } \\
\text { likely result is a decrease in student learning. }\end{array}$ & $44.4 \%$ yes & $55.6 \%$ no \\
\hline $\begin{array}{l}\text { Question 12: } \\
\text { I generally adhere to a consistent format and actions for } \\
\text { each session I teach. }\end{array}$ & $70.4 \%$ yes & $29.6 \%$ no \\
\hline $\begin{array}{l}\text { Question 13: } \\
\text { I would rather just give students specific information than } \\
\text { spend time guiding their thinking towards the answer. }\end{array}$ & $18.5 \%$ yes & $81.5 \%$ no \\
\hline
\end{tabular}

\section{Discussion}

A comparison of the closed and open-ended results from this survey has produced contrasting yet interesting results. Firstly, the closed questions demonstrated that a majority of respondents favoured learner-centred over teacher-centred descriptions. More specifically, for Questions 5 to 7, at least two in three respondents chose the learner-centred options. The remaining options chosen by respondents in Questions 8 to 13 also provided majorities favouring learner-centred approaches, however, the degree of this majority varied with the question. Despite these majorities, there still remained a 'core' of around one third of staff preferring teacher-centred strategies. 
An analysis of the open-ended questions indicates an opposing conclusion to the closed questions. More than half of the descriptions provided in Questions 1 and 2 do not extend beyond Category 1 of Åkerlind’s framework, indicating a perception of teaching development limited to the acquisition of content knowledge to become more familiar with teaching. Whilst responses in Category 1 decreased in Question three to $18.5 \%$, there was also an $18.5 \%$ response in Category 2 and $18.5 \%$ not matching any category. There is a majority of respondents not extending their descriptions beyond the first two categories across the first three questions.

What are generally consistent across the first three questions are the responses to categories three, four and five. Category 3 had either nine or 10 matches, indicating that around one in three respondents valued increasing their repertoire of teaching strategies. However, despite these responses demonstrating a more sophisticated appreciation of teaching development than Categories 1 and 2, they do not yet include descriptions of reflecting on practice to improve teaching (Category 4) or a focus on facilitation to improve student learning outcomes as an indicator for successful teaching (Category 5). More specifically, Åkerlind (2008) suggests,

... that discernment of the need to develop a good repertoire of teaching methods and strategies as part of developing as a teacher, without an accompanying discernment of the need to focus on the implications of these strategies for student learning, is associated with a teacher-centred conception of teaching (p. 642, emphasis in original).

This suggestion emphasises that, whilst the descriptions in Category 3 made mention of increasing their repertoire of strategies, their lack of focus on student learning indicates they still tend more towards being teacher-centred rather than learner-centred. Category 5, the most complex and inclusive approach, represents a truly learner-centred teacher (Åkerlind, 2007); however, only two responses matched this category in the first question and one each in Questions 2 and 3. With only one match for Category 4, responses beyond the descriptions of Category 3 represent only a small proportion of $7.7 \%$ or less across the first three questions, indicating a significant majority of respondents possess less sophisticated or teacher-centred understandings of teaching and developing as teachers.

There is a disproportionate emphasis in the open-ended questions upon subject content and teacher-centred descriptions, at the expense of responses describing reflective practice and/or learner-centred facilitation. This is in contrast to the closed questions indicating a majority of respondents preferring more learner-centred descriptions. One reason for the higher learnercentred responses in the closed questions could be that teachers at the College were attempting to choose the 'right' answers. Whilst the survey was intentionally conducted prior to the intensive facilitation workshops in January 2010, respondents would still have been aware of the PBL implementation being promoted within the College and its points of contact with this survey. So more learner-centred practices in the survey might have been selected despite doubts respondents may have about these approaches or whether they actually use them in their practice.

Another potential limitation in relation to the narrative responses could relate to the relatively brief descriptions given by respondents to these questions. Unlike an interview scenario, where rich descriptions can be given and clarifications made, respondents to this survey may have felt pressured by time and not fully elaborated their thoughts in relation to their teaching practices and development, thus limiting their ability to outline more sophisticated understandings. However, as previously mentioned, the Åkerlind framework was used as a general guide, with individual responses not being required to match every specific aspect of a category to be included.

Aside from the limitations mentioned, there are other possible explanations as indicated in the work of various researchers into teaching approaches and conceptions. Murray and Macdonald (1997) identified some confusion in their study of lecturer perceptions of teaching in a business school in the United Kingdom. In particular, they highlighted that staff beliefs about their teaching 
role did not always match their intentions or actions in the application of teaching. Samuelowicz and Bain (1992) also highlighted this in their studies, describing it as

... one of the mysteries of higher education - the disjunction between the stated aims (promotion of critical thinking) and educational practice (unimaginative coverage of content and testing of factual recall) (p. 10).

Murray and Macdonald (1997) proposed a number of explanations for this disjunction between teaching ideals and the actual experiences of practitioners. Firstly, they suggest that contextual issues can militate against the application of teaching ideals. In the context of this survey, the majority of participants chose statements that reflected ideals of promoting critical thinking; however, when asked to articulate the attributes of staff at the College and their own teacher development, their narrative descriptions tended to fall short of learner-centred ideals and tended to focus more on the coverage of content. The bias towards content over learning process was also displayed in responses to Question 4 and the narrative responses in Questions 5 to 7 described above. Some of these responses agreed with the importance of supporting thinking processes, however, these responses also highlighted clear beliefs amongst a number of participants that students' knowledge of subject content would suffer if too much emphasis was placed on learning processes. There was also concern that a loss of teaching time would reduce opportunities to 'cover' content. Many of these narrative responses are a function of the context of teaching practice at the College and seem to represent what participants perceive to be the 'reality' of their teaching lives, especially in terms of limited time and large quantities of content to 'cover'. Prosser, Ramsden, Trigwell and Martin (2003) describe in their studies that teachers who perceive they have less control over their environment, in terms of matters such as class sizes, workloads, and the value placed on teaching by management, are more likely to resort to teacher-centred approaches. Thus, contextual issues, whether they be justified or not, appear to be used by some teachers as a reason for highlighting more teacher-centred approaches in their descriptions.

A second explanation put forward by Murray and Macdonald (1997) relates to the distinction between espoused theory and theory-in-use proposed by Argyris and Schön (1978). Espoused theory represents what a teacher might declare publicly in relation to their beliefs and views of their role, whilst theory-in-use is based on undeclared values and strategies that do more to inform their practice. Murray and Macdonald (1997) suggested participants in their study may have been influenced by what they should say. This has already been alluded to in this discussion, when it was suggested that respondents made what they thought were the 'right choices' in light of the advertised move to a more learner-centred practice in PBL. Bowden (2005) in a discussion about selecting research interview questions, suggests avoiding direct 'what is X?' questions, as they tend to only elicit standard theoretical responses found in broader literature. It can be argued the closed questions in this survey represent these types of standard responses. Bowden (2005) instead recommends asking people to describe their own experiences in order to achieve a deeper insight into their individual conceptions or beliefs. The open-ended questions in this survey do appear to give greater scope for respondents to reflect upon and describe their experiences, rather than simply choose the correct theoretical response. This would suggest these questions represent more authentic responses by participants in relation to their teaching than the closed questions.

Murray and Macdonald (1997) also suggest that this disjunction between espoused theory and theory-in-use arises because participants highlight what they would like to do, but may be unable to do. This suggestion is certainly possible in the context of this survey. An example of this can be seen in several responses to Question 4, where participants stated they are already doing PBL in their practice, which was not the case at the time of the survey. Interestingly, Argyris and Schön (1978) indicate people are often not aware their theories-in-use are not the same as their espoused theories, and they are often unaware of their theories-in-use. They suggest that in cases such as this, attempts should be made to develop congruence between the two theories so people can become more aware of the application of theory into practice. Murray and Macdonald (1997) suggest reflective practice should be encouraged amongst teachers to assist in this process. The lack of descriptions from participants matching Category 4 of the Åkerlind framework indicates 
only a very limited number of staff possess the mechanisms to highlight the differences between their espoused theories and theories-in-use.

A final explanation put forward by Murray and Macdonald (1997), which stems from the previous explanation, is the suggestion that more teacher development is needed for staff to put their perceived role, or espoused theory, into operation. The open-ended responses in this survey have indicated a need for staff to expand their awareness of teaching practices to include the higher order categories described by Åkerlind (2007). Whilst one in three indicated a need to increase their repertoire of teaching strategies, very few staff were able to articulate the key aims of student focused facilitation so crucial to the effective facilitation of learner-centred approaches like PBL. In fact, more than half the respondents did not describe any need to improve teaching skills at all, instead relying upon their police knowledge and/or experience. This propensity for content knowledge at the expense of developing learner-centred teaching can also be found in the narrative responses to Questions 4 to 7. Even in relation to the closed questions, where a majority have tended to choose learner-centred statements, there is doubt all of these actually relate to their theories-in-action. If this is so, staff will still require teacher development to put their espoused theories into action. Overall, the findings from this survey highlight the need for staff development within the area of teaching and learning, with a specific focus on encouraging reflective practice and learner-centred approaches to re-enforce the implementation of PBL within the NSW Police College.

\section{Implications for learning design}

There are some key implications from this study and the broader literature in relation to the design of staff development for the NSW Police College. This issue could potentially relate to other police training institutions, especially given the findings of Werth (2009) in relation to staff at a PBL police academy in North America still favouring teacher-centred conceptions.

A number of academics have highlighted the need for staff development in higher education that challenges underlying beliefs of teaching via experiential and reflective learning activities and addresses teachers’ underlying conceptions (Åkerlind, 2007; Hendry, 2009; Irby, 1996; McKenzie, 2003; Trigwell \& Prosser, 1996). Essentially, this contemporary approach to staff development encourages teachers to perceive a wider range of variations in teaching practices. For example, Trigwell and Prosser (1996) in their development activities help participants perceive these variations by encouraging them to examine their experiences and those of their students to make connections between their ideal conceptions of teaching and specific approaches in the classroom. McKenzie (2003) also emphasises the need to create space for variation and suggests strategies should be used to make participants aware of the broader variations highlighted within the frameworks similar to that used in this paper and encourage more learner-centred conceptions. From the findings relating to the phenomenographic framework used in this paper, Åkerlind (2007) suggests staff development programs should provide opportunities for conceptual expansion, where teachers' current beliefs are challenged and they are exposed to qualitatively different ways of improving their students' learning.

More specifically, the variation theory of learning, stemming from phenomenography, suggests conceptual development should be encouraged via opportunities for individuals to experience different aspects of variation of a phenomenon they currently take for granted (Marton \& Tsui, 2004). Four key design strategies to promote variation include:

1. Contrast - for example, comparing learning with teaching in order to draw attention to differences between them and highlight aspects a teacher was previously unaware of.

2. Generalisation - for example, making someone aware of the different conceptions of teaching. Combined with contrast, this allows for the further separation of features and becoming aware of phenomena that were previously unknown. 
3. Separation - for example, separating the roles of teaching and learning to experience some features whilst others remain invariant.

4. Fusion - should follow separation in order for a person to now become aware of all the essential features as they happen at the same time. For example, how teaching and learning practices interact with each other in the classroom but now with more clarity as both roles were previously highlighted individually (Marton \& Tsui, 2004).

Some suggested design approaches to staff development activities, inspired by Åkerlind (2008), include the following. A class of staff members at the beginning of a developmental activity could be asked to each outline their teaching goals, what they do as teachers and explanations as to why they do this. A similar process could also undertaken to outline their learners' goals, what their students do and why. This activity encourages participants to contrast the roles of teaching and learning. The class could then asked to share their findings with other members via small learning groups and then a wider plenary discussion. These activities provide an opportunity for generalisation, as participants are exposed to wider awareness through the variations in views of other participants. This allows participants with teacher-centred conceptions, who would more than likely have a greater emphasis on their role, to view how more learner-centred participants value their learners and facilitate their learning, with a greater focus upon what the learner is doing. These activities may also provide opportunities for participants to contrast differences between their espoused theories and theories-in-use, especially as they reflect upon specific experiences in the classroom.

Åkerlind (2008) suggests that whilst activities utilising contrast and generalisation may also provide opportunities for separation, the use of separation is best undertaken while keeping key features invariant. A particular example of this can be taken from the research of Prosser and Trigwell (1999), where they use quotes from two separate students describing the same lecture. This demonstrates separation whilst the activity of the teacher is kept invariant. In this case, the description of the first student describes a very theory based lecture, where the focus of the student is to write down study notes. However, the second student describes a non-didactic lecture involving buzz sessions and the lecturer asking questions prompting students to think deeply about problems they were given in the lecture. Our class of staff members could be asked to read these separate quotes and analyse the differences in small groups prior to a plenary discussion. Prosser and Trigwell (1999) actually note the surprise their own students express upon being told each student was responding to the same lecture. By separating learning from teaching but keeping the teaching role invariant, this activity demonstrates the potential for variation in the student experience, which is essential for a teacher to understand if they are to move towards a more learner-centred conception ( $\AA$ kerlind, 2008). At the end of their development program, there would be an opportunity for fusion via a learning journal entry that asks participants to reflect upon their initial responses in the first activity to teaching/learning goals and rewrite these responses given their new learning. This allows participants to draw together the various components of teaching and learning presented during the course in a holistic manner.

A similar approach to these theories has been taken in the recent workshops being conducted for the NSW Police College. Whilst they are not specifically informed by variation theory, they are experientially based, with a range of advanced adult education methods, including PBL, being modelled and practiced. This experience required participants to be immersed in participative activities with groups of their peers, with reflection upon their learning and their emotional intelligence via learning journals. Rather than prescribing an approach to PBL, as traditional staff development programs might do, this workshop was designed to explicitly challenge participants underlying conceptions and experience learner-centred approaches. This approach helps participants to become more aware of variation in teaching and learning practices, with the aim of developing more sophisticated conceptions and helping to put espoused theories into action in the classroom. It is anticipated that staff at the NSW Police College will replace the original workshop consultants and assume the role of designing and facilitating future staff development activities. The use of activities inspired by variation theory described above could be used to augment the techniques demonstrated by Cleveland and Saville (2007). 
Whilst it appears staff development approaches at the NSW Police College are providing the direction clearly required by its police educators, it will be some time before the results of this program are clear. The limitations of this study have also indicated a need for further qualitative research to elaborate upon the teaching conceptions of staff. Research from the interpretive and critical perspectives within police education programs worldwide has been limited, however this approach could provide valuable insights into the teaching practices of police educators in this area. It is proposed that a study utilising phenomenographic methods be conducted with staff at the NSW Police College to explore conceptions of developing and growing as teachers within the context of police education and a PBL implementation. This proposed study should provide an outcome space highlighting different levels of awareness and a framework for specific developmental design recommendations based on variation theory.

\section{References}

Åkerlind, G. (2003). Growing and developing as a university teacher - Variation in meaning, Studies in Higher Education, 28(4), 375-390.

Åkerlind, G. (2007, February). Constraints on academics’ potential for developing as a teacher, Studies in Higher Education, 32(1), 21-37.

Åkerlind, G. (2008, December). A phenomenographic approach to developing academics’ understanding of the nature of teaching and learning. Teaching in Higher Education, 13(6), 633-644.

Albanese, M.A., \& Mitchell, S. (1992). Problem-based learning: A review of literature on its outcomes and implementation issues. Academic Medicine, 68(1), 52-81.

Argyris, C., \& Schön, D. (1978), Organizational learning: A theory of action perspective. New York: McGraw-Hill.

Barrows, H.S,. \& Wee Keng Neo, L. (2007). Principles and practice of a PBL. Singapore: Pearson - Prentice Hall.

Berg, B.L. (1990). Who should teach police: A typology and assessment of police academy instructors. American Journal of Police, 9, 79-100.

Biggs, J. (1978). Individual and group differences in study processes. British Journal of Educational Psychology, 48, 266-279.

Biggs, J. (1999). What the student does: Teaching for enhanced learning. Higher Education Research \& Development, 18(1), 57-75.

Birzer, M.L. (2003). The theory of andragogy applied to police training. Policing: An International Journal of Police Strategies and Management, 26(1), 29-42.

Bloss, W.P. (2004). Creating critical thinkers: Interactional Approaches to Police Instruction. Law Enforcement Executive Forum, 4(5), 147-162.

Bowden, J. (2005), Reflections on the phenomenographic team research process. In J. Bowden \& P. Green (Eds.), Doing Developmental Phenomenography (pp. 103-127). Melbourne, Australia: RMIT University Press.

Bradford, D., \& Pynes, J. (1999). Police academy training: Why hasn't it kept up with practice? Police Quarterly, 2(3), 283-301.

Braun V., \& Clarke, V. (2006). Using thematic analysis in psycholog., Qualitative Research in Psychology, 3, 77-101.

Chappell, A.T. (2005) Learning in action: Training the community policing officer. Unpublished PhD Dissertation, University of Florida.

Cleveland, G., \& Saville, G. (2007). Police PBL, Blueprint for the $21^{\text {st }}$ century, CommunityOriented Policing Services, US Department of Justice and Regional Community Policing Training Institute, Wichita State University. Retrieved January 1, 2011, from http://www.pspbl.com/pdf/PolicePBLBook2007.pdf

Conti, G.J. (1989). Teaching styles and the adult basic educator. In M.C. Taylor \& J.A. Draper (Eds.), Adult Literary Perspectives (pp.311-317). Toronto, Canada: Culture Concepts.

Dahlgren, M.A., Castensson R., \& Dahlgren, L.O. (1998). PBL from the teachers’ perspective, Higher Education, 36, 437-447. 
Dochy, F., Segers, M., Bossche, P., \& Gijbels, D. (2003). Effects of problem-based learning: A meta-analysis. Learning and Instruction, 13(5), 533-568.

Entwistle, N., \& Ramsden, P. (1983). Understanding student learning. London: Croom-Helm.

Gardner, H. (2004). Changing minds: The art and science of changing our own and other people's minds. Boston, MA: Harvard Business School Press.

Goleman, D. (1996). Emotional Intelligence: Why it can matter more than IQ. London: Bloomsbury.

Hendry, G.D. (2009). Problem-based learning tutors' conceptions of their development as tutors. Medical Teacher, 31(2), 145-150.

Irby, D.M. (1996). Models of faculty development for problem-based learning. Advances in Health Sciences Education, 1, 69-81.

Kember D., \& Gow, L. (1994). Orientations to teaching and their effect on the quality of student learning. The Journal of Higher Education, 65(1), 58-74.

Kember D., \& Kwan, K. (2000). Lecturer's approaches to teaching and their relationship to conceptions of good teaching. Instructional Science, 28, 469-490.

Kember, D. (1997). A reconceptualisation of the research into university academics' conceptions of teaching. Learning and Instruction, 7(3), 255-275.

Kember, D. (2009). Promoting student-centred forms of learning across an entire university. Higher Education, 58, 1-13.

Marion, N. (1998). Police academy training: Are we teaching recruits what they need to know? Policing: An International Journal of Policing Strategies \& Management, 21(1), 54-71.

Martin, E., \& Ramsden, P. (1992). An expanding awareness: How lecturers change their understanding of teaching. Paper presented at the 1992 HERDSA Conference, Gippsland. Retrieved January 1, 2011, from http://www.herdsa.org.au/confs/1996/mckenzie2.html

Marton, F., \& Saljo, R. (1976). On qualitative differences in learning. I - Outcome and process. British Journal of Educational Psychology, 46, 4-11.

Marton, F., \& Tsui, A.B.M. (2004). Classroom discourse and the space for learning. Mahwah, NJ: Lawrence Elbraum Associates.

McCoy, M. (2006). Teaching style and the application of adult learning principles by police instructors. Policing: An International Journal of Policing Strategies \& Management, 29(1), 77-91.

McKenzie, J. (1999). Changing teachers' ways of experiencing teaching and ways of experiencing teaching change: How do they relate and what are the implications? HERDSA Annual International Conference, Melbourne, July 12-15. Retrieved January 1, 2011, from http://www.herdsa.org.au/branches/vic/Cornerstones/pdf/McKenzie.PDF

McKenzie, J. (2003). Variation and change in university teachers' ways of experiencing teaching. Unpublished Doctoral Thesis, University of Technology, Sydney.

Murray, K., \& McDonald, R. (1997). The disjunction between lecturers' conceptions of teaching and their claimed educational practice. Higher Education, 33, 331-349.

Norman, G.R., \& Schmidt, H.G. (1992). The psychological basis of problem-based learning: A review of the evidence. Academic Medicine, 67(9), 557-565.

Prosser, M., \& Trigwell, K. (1999). Understanding learning and teaching: the experience in higher education. Buckingham,UK: Open University Press.

Prosser, M., Ramsden, P., Trigwell, K., \& Martin, E. (2003). Dissonance in experience of teaching and its relation to the quality of student learning. Studies in Higher Education, 28(1), 3748.

Ramsden, P. (1992). Learning to teach in higher education. London: Routledge.

Samuelowicz K., \& Bain, J.D. (2001). Revisiting academics’ beliefs about teaching and learning. Higher Education, 41, 299-325.

Samuelowicz, K., \& Bain, J.D. (1992). Conceptions of teaching held by academic teachers. Higher Education, 24, 93-111.

Savery, J.R. (2006). Overview of problem-based learning: Definitions and distinctions. The Interdisciplinary Journal of Problem-based Learning, 1(1), 9-20.

Trigwell, K., \& Prosser, M. (1996). Changing approaches to teaching: A relational perspective. Studies in Higher Education, 21(3), 275-284. 
Trigwell, K., \& Prosser, M. (1997). Using phenomenography in the design of programs for teachers in higher education. Higher Education Research \& Development, 16 (1), 41-54.

Trigwell, K., Prosser, M., \& Waterhouse, F. (1999). Relations between teachers' approaches to teaching and students' approaches to learning. Higher Education, 37, 57-70.

Werth, E.P. (2009). Problem-based learning in police academies: Adult learning principles utilized by police trainers. Unpublished Doctor of Education dissertation, Liberty University.

\section{Acknowledgments}

The author would like to acknowledge the thoughts and feedback from Dr Anna Corbo Crehan that assisted in the writing of this paper.

Copyright @ 2011 Brett Shipton 